\title{
THE RELATIONSHIP BETWEEN SOCIAL ROLES OF CONTEMPORARY ART MUSEUMS AND DIGITALIZATION
}

\author{
Atiye Güner $^{1}$ (D), ismail Erim Gülaçtı² ${ }^{2}$ \\ ${ }^{1}$ Yıldiz Technical University, Student in Art and Design PhD Programme, Istanbul Turkey \\ Hasan Kalyoncu University, Faculty of Communication, Visual Communication Design \\ Department, Gaziantep, Turkey \\ ${ }^{2}$ Yıldiz Technical University, Faculty of Art and Design, Department of Art, istanbul Turkey
}

\begin{abstract}
This paper was adapted from the author's PhD dissertation named "The Effects of Digitalization on Contemporary Art Museums and Galleries".

The digital age has started with the digitalization of information and information communication. The digitalization processes that accelerated with the rapid developments in information and communication technologies have deeply affected museums. Museums are information-based organizations, their primary functions are to protect and spread information. Digitalized information and information communication have obligated contemporary art museums to follow digitalization processes. In this process, technological convergence is another factor that accelerates digitalization of contemporary art museums.

ICOM has defined a contemporary museum as a polyphonic platform including participatory, inclusive and democratizing elements. When all these concepts are considered, the importance of communication between museum-community becomes apparent. Today, contemporary art museums have taken communication to their focal points. Museum-society communication is experienced in contemporary art museums through artistic activities as well as institution's communication-oriented strategies. Contemporary art activities using digital technologies and multimedia technologies generally require audience participation. Global access and various digital platforms provide the society with equal access to museums and art events, as well as making the arts of various countries and identities more visible. In the field of education, contemporary art museums develop projects by cooperating with various institutions. The effective use of digital platforms and institutional pages serves as a catalyst in the realization of these roles that museums undertake. Innovations in information and communication technologies accelerate the digitalization processes and serve as a mediator in maintaining the social roles of museums. For example, it can be said that technological convergence increases the number of museum visitors, therefore, it is the mediator of the social roles of museums. Technologies such as virtual reality, augmented reality and artificial intelligence, which are used in exhibition design in museums, require audience interaction. Digital art based on digital technology takes its place in contemporary art museums. In this study, it was aimed to reveal that social roles undertaken by contemporary art museums, such as participatory, inclusive, democratizing and polyphonic roles, are closely related to the digitalization of institutions and that digitalization acts as a catalyst for these roles.
\end{abstract}

Key words: Contemporary Art Museums, Social Roles of Museums, Communication Function in Museums, Digitalization Process

\section{INTRODUCTION}

Today, the rapid digitalization of communication technology affects contemporary art institutions in the direction of digitalization. Information/data was the first units that were digitalized in the digital age. The fact that digitalized information can be easily stored, transferred, online and quickly accessed has transformed museums from being static spaces to a state where virtual exhibitions and collections are easily accessible in high-resolution image format. The online, accessibility and virtual feature of information communication and digital technology affects not only the functions of storing and preserving the information but also the social functions of museums in the direction of digitalization; the social process called digitalization transforms the functioning and purposes of art institutions as well as the various areas of life.

As mentioned in the section of Contemporary Art Museums and Their Social Roles, museums that have changed since the 1970s have been redefined and their functions have shifted from object-focused to human-focused (table1). Thus, for museums, strong communication with the society means being a strong social institution. 
Table 1: The changing functions of museums

\begin{tabular}{|l|l|l|}
\hline functional & $\begin{array}{l}\text { Museums acquires, preserves, communicates, exhibits for educational and } \\
\text { artistic purposes. }\end{array}$ & object-based \\
\hline purposeful & $\begin{array}{l}\text { Museums are places where people can have fun and learn from collections } \\
\text { that have reliable information and have equal access. }\end{array}$ & human-based \\
\hline
\end{tabular}

Adopted from Rentschler Ruth. Museum Marketing: Understanding Different Types Of Audience (Arts Marketing, London: Routledge 2004).

Digital platforms that function as socialization areas have become platforms where contemporary art museums communicate with the society and with each other. In contemporary art museums, digital technologies have been an instrument for ensuring social participation by creating different spatial perceptions. Thus, the concept of the audience, which is both the source and the receiver of information, has also been transformed.

\section{METHOD}

In this paper, the relationship between the social functions of contemporary art museums for public interest and digital technology has been questioned. The main problem of the study is the question of whether digital technology and digital platforms will cause a change in the social functions of a contemporary art museum because in the digitalization process, we can mention existence of cyberspace as an environment. Cyber space is a virtual environment that have all kinds of information which get electronized through connections such as telephone cables, internet, connection cables, and fiber optic lines. The reality perceptions of the society undergo a change of paradigm towards virtualization. With these effects, the characteristics of each organism and institution are being reshaped in cyberspace. Within the framework of this basic problem, data were collected from the literature, printed and accessible sources, related pages and videos that has been accessed on the internet.

In this article; Contemporary Art Museums and Their Social Roles, Digitalization and Use of Digital Technology in Contemporary Art Museums are examined in two main sections and then concluded.

\section{CONTEMPORARY ART MUSEUMS AND THEIR SOCIAL ROLES}

The museums that emerged for scientific purposes continued their existence for the same purposes during the Renaissance and Enlightenment. In the 18th century, royal collections were transformed into modern museums in Europe. Thus, museums played a role in the construction of nation states as a public space (Artun, 2006). Art museums have been seen as institutions in which autonomy in art is structured since this era. In the 20th century, the attitude of avant-garde art towards the autonomization and institutionalization of art and the questioning of the museum institution by the avant-garde and post-art movements in this context caused art museums to reach a different consciousness with contemporary understanding. Thus, a new understanding of museology has dominated since the 1970s.

The 1980s point out the one important development in terms of museology. With the globalization that reached a peak in this period, ethnic identities were questioned and multicultural understanding prevailed. For this reason, museums are also questioned with support of postmodernist ideas. Identities and societies that had not been adequately represented until then, were embraced both politically and culturally, and their works were included in contemporary art museums. During this period, the business culture which is created by neoliberalism also affected museums (Yücel, 2012b). Thus, the effect of business culture, postmodernist inquiries and the change in understanding of representation in museums in this context have developed the understanding of contemporary museology. In the contemporary understanding of museology, emphasis on the social functions of museums has increased. The public interest has emerged as an important function of museums.

The International Council of Museums ICOM shares an alternative definition for voting at the ICOM Extraordinary General Congress held in Kyoto, Japan on 7.09.2019

Museums are democratising, inclusive and polyphonic spaces for critical dialogue about the pasts and futures. Acknowledging and addressing the conflict and challenges of the present, they hold artefacts and specimens in trust for society, safeguard diverse memories for future generations and guarantee equal 
rights and equal access to heritage for all people. Museums non for profit. They are participatory and transparent, and work in active partnership with and for diverse communities to collect, preserve, research, interpret, exhibit and enhance understandings of the world, aiming to contribute to human dignity and social justice, global equality and planetary wellbeing (ICOM, 2019).

This definition agrees that museums are non-profit institutions, just like the definition in the current ICOM statute which is adopted by the 22nd general assembly in Vienna on 24 August 2007. The permanence emphasized by the current definition has changed with the alternative definition in 2019 that museums are polyphonic organizations that cooperate with active partnerships to achieve their transparent, participatory, inclusive goals at the level of global equality and prosperity. As seen in the definition, social roles of museums are emphasized as well as preservation, research, exhibition and communication. The democratizing, participatory and inclusive social roles of museums and in this context, their communication with their internal and external environments have been prominent values.

\subsection{Social Functions of Contemporary Art Museums}

The factors that increase the power of contemporary art museums are that museums develop face-toface communication opportunities, they are responsible for creating their own resources; they collaborate with various institutions and communities to develop their curatorial work, they apply creative solutions regarding technology and design, and they prioritize communication in planning exhibitions and events (Ertürk and Uralman, 2012). The museums, which previously take responsibility only for their collections and which adopt an object-centered approach, today are based on social sharing. They aim to integrate with the society through a visitor and communication-based approach. For these reasons, the fact that museums are inclusive, democratizing and polyphonic platforms is closely linked to the improvement of their communication with the society.

Social responsibility undertaken by contemporary art museums brings prestige to companies and groups. In this context, museums have taken care to be transparent and accessible due to the sanctions of the laws, non-governmental organizations and the prestige they will gain. For example, even though the private sector supports the museums in the USA, they are operated as a public institution and take social responsibility. American Associations of Museums (AAM), a private institution that inspects museums in the United States, publishes an accreditation list every year based on the compliance of museums with ethical rules in the public sense (Köksal, 2016). Being included in this list is important for museums since according to this variable the number of viewers, donors and membership increases.

The social functions of museums can be listed under the titles of democratization and inclusiveness. Education and participation functions can also be examined within the functions of inclusiveness and democratization. The education and training programs organized by museums serve a democratizing function by ensuring the equal distribution of knowledge. The increase in social functions of today's museums and the museums' caring for public interest, as Atagök says (2012, 172-173), starts with museums seeing themselves as an educational institution. Thus, museums ceased to be an authoritarian institution, and gained the characteristic of being a participatory institution serving the values of the society, questioning historical and cultural values, activating the audience who questioned them.

Contemporary art museums play a role in creating public space in the context of inclusive museology. The organized exhibitions, events and projects are social functions in terms of creating a public, i.e., critical space. The inclusiveness and democratization function defines the place of a contemporary museum in the globalizing world. According to Maleuvre $(2012,112)$, the inclusive understanding of museology makes cultural institutions sensitive to the public and this specific understanding ensures the democratization of the culture. Inclusivity has brought the approach that the museum provides equal access to information, as well as keeping different cultures together, causing museums to become polyphonic platforms. Thus, an inclusive museum provides access to information by revealing overlooked information and provides equality with the representation of underrepresented identities.

The concept of inclusive museology, which emphasizes the social functions of museums, means much more than being accessible for a large group. The strategies to attract masses who are not in the habit of visiting the museum reflect the understanding of inclusive museology. As stated by Özalp Birol (Birol, 2018), General Manager of Suna and Inan Kıraç Foundation Culture and Art Enterprise, this understanding transforms contemporary art museums into places in which various curatorial projects organized for education, training, entertainment, guided tours, screenings, conferences, performances, etc. and in which the audience is included in art events. It has also transformed it into multifunctional show venues where products are marketed, such as commercial businesses. 
The Center Pompidou, founded in Paris in 1977, can be cited as the first example of the transformation of contemporary art museums into a multifunctional and targeted state. Center Pompidou is a new cultural center project on a private estate in Paris, consisting of a large public library, a museum with a national modern art collection, large halls for design, music research, permanent exhibition galleries, theater, seminar, concert film screening. It is a cultural project announced by President Georges Pompidou in 1969, which he thinks will make Paris superior in international art (Lorente, 2016). It reached immense popularity after its official opening on January 31, 1977. The detection of Lorente for Pompidou, which spans an area of 65,000 square meters with about seven million visitors a year, is interesting. Four-fifths of the people who visit the museum in a year are people who have never been interested in the museum section. This determination shows that the concept of inclusive museology has increased the museum audience, and in the 21st century, museums are not only institutions that convey information, but show centers focusing on the public good, as in the 19th century.

Fulfilling the social functions of museums also requires a participation factor. British Museum Object Journeys Project Manager Kayte McSweeney (McSweeney, 2018) states that contemporary museums are not detached from the public but they show a participatory attitude towards the public. The participatory approach that developed in the 1990s is necessary for the democratization of culture and heritage, and it requires audience cooperation as well as partnerships and the multiplication of stakeholders. The participatory approaches of museums aim not only for the passive participation of people in museum activities but also for active participation in a wide variety of ways. Participation in the field of culture is a concept that includes people attending cultural events, participating in artistic and intellectual creation processes, cooperating with cultural institutions, taking part in decision-making processes in the field of culture and interacting with each other.

\section{DIGITALIZATION AND THE USE OF DIGITAL TECHNOLOGIES IN CONTEMPORARY ART MUSEUMS}

Neoliberal economies that have developed with the effects of globalization since the 1980s have turned art into an investment tool. Contemporary art institutions have turned into an element of power on an international scale. One of the factors that prepared this situation is the changes in information communication technologies (ICT) and the rapid spread of the internet.

Information communication technologies and internet carry out all kinds of information / data communication in a very short time. Thus, the perceptions of speed, time and space have also transformed, causing changes in communication, finance, production, consumption, social structures and the functioning of institutions. For example, according to Manuel Castells (Castells, 2000), all processes of our individual and common existence are directly determined by new technology, the raw material of which is knowledge. After a while, Alvin Toffler defines highly electronic third-wave civilization whose basic raw material is knowledge and imagination (Toffler, 2018). During the same period (1980s) Japanese sociologist Yoneji Masuda emphasizes that the driving force behind contemporary society is not material values as in industrial society, but digitalized knowledge (Masuda, 2004). The new social framework in which the information society is established is based on the analysis of computer and communication technology. As communication shifts from analog technologies to digital ones like information (e-mail, chat, social media), both business and social life become digital.

Digitalization is done by digitalizing the data taken from analog life. Feldman (Feldman, 1997) defines the properties of digital data as the keys to their potential effects on our lives. These features of the data are that; they are manipulable (changeable), networkable (networkable), dense (dense), compressible (compressible), impartial (neutral). According to Atabek (Atabek, 2001), the difference between analog and digital technologies can be explained by the definition that the analog is real and the digital one simulates the reality.

Information / data can be changed, compressed, recorded, copied and reproduced, its rapid dissemination has brought forward information / data communication in the 21st century. For these reasons, museums, which are basically knowledge-based institutions, attach great importance to their interaction and communication with the society in order to compete on a global scale and to maintain their existence and power. In addition to its basic functions such as storing, preserving and transferring information, ICT and internet usage is very important in fulfilling the display, public and institution communication, promotion, marketing and social functions that can be examined under communication functions. 


\subsection{Examples of Social Functions of Museums Performed by Digital Technology}

Digitalization has made it possible for museum / gallery collections to be displayed on the internet since the 1990s and brought the concept of virtual museum / gallery created in a digital environment to the agenda (Yücel, 2012a). A virtual museum is more than digitalizing collections and having a web page. For example, according to Schweibenz (Schweibenz, 2004), a virtual museum is not just a museum that has a web page and makes its collections accessible. Schweibenz, in his article The Development of Virtual, described the virtual museum as the highest level of internet applications implemented in a museum. This stage is the virtual museum that offers visitors easily accessible connected digital objects and information, and can be opened to an interactive dialogue using multi-media technologies.

"For me, Twitter was a great thing to discover. I opened my work and went beyond Kiasma's walls and expanded my work in the outside world. "Senior Planning Officer, Public Programs Department of Kiasma Museum Sanna Hirvonen summarizes the relationship between social media and contemporary art museums in this way (Project-musa, 2020). Social networks created with Web 2.0 technology, which has features such as mutual interaction and content management, developed after the 2000s, have been one of the platforms where museums communicate with the public. Social media platforms such as blocks, micro blogs, RSS feeds, forums, communication sites, picture-video sharing sites are the visible face of contemporary art museums in society.

Live broadcasts on social media and digital platforms have become a tool for contemporary art museums to create a public space and defend global problems and the rights of oppressed and different identities. Thus, contemporary art museums fulfill their social functions by highlighting social problems and creating platforms for public criticism. For example, Tate has been broadcasting live streams on Facebook since June 2016 and on Instagram since March 2017. In 2018, before the Deaf Awareness Week, he published a live exhibition tour on Facebook with the first British Sign Language (BSL) in the UK cultural sector, and he examined three works of Picasso in detail. Instagram live streams were posted as a number around LGBTQ + themes (Tate, 2019). Tate, 2019 ' Emphasizing that women were not sufficiently represented in art during the Women's History Month, she made live broadcasts on Facebook and Instagram. According to the latest annual (2018-2019) report shared by Tate, Tate Modern was among the top three museums in the world geotagged by the Instagram community in 2018, and its Instagram followers grew by thirty-two percent.

The highly developed virtual exhibition platform offered by Google Art Project and Google's Open Gallery software are advanced examples of virtual museums / galleries. Google Art Project is a virtual museum project and museums participating in this platform have the opportunity to add visuals and develop applications for various works. Technologies such as Google Street View Street View are used to provide 3D images. Through "Create an Artwork Collection" offered by the Create an Art Collection feature, viewers can create and comment on their virtual collections (A Single Museum on the Internet: Google Art Project, 2012). Google Art and similar projects reveal the importance of contemporary museums' communication with each other and common platforms.

A traditional art museum informs the public by displaying certain objects and images and opening them to historical comparisons, analysis and theoretical thinking. This position based on interpretation in the face of art keeps the viewer's gaze in the work of art (Groys, 2017). In the contemporary art museum, with the effect of technology, the viewer's gaze has turned to the process of documenting the art event from inside and outside, the positioning of this process in the media space, in other words, the spatial boundaries of the event. Thus, the perception of the museum space has transformed as the processes of obtaining and spreading information are transformed with communication technology. The audience was included in the artistic activity and projects and took part in the co-creation function of a participatory museum.

The fact that digital technologies facilitate access and create the interaction feature in the implementation of projects, and the advantages of technological convergence in all kinds of virtual, visual and audio participation are a factor that increases the participation of a contemporary museum. For example, the Louvre Museum presented its first virtual reality (VR) application between October 24, 2019 and February 24, 2020 at Napoleon Hall with the project named Mona Lisa: Beyond the Glass. In a virtual reality room, the project realized by Louvre in collaboration with HTC VIVE Arts, was experienced by a virtual reality glasses developed by HTC and SteamVR. Besides, the project was experienced worldwide through mobile phones having iOS, Android and other operating systems (VIVE Arts, 2020). Digital viewers also had a virtual visit to the Louvre Museum and they access to the Louvre's permanent collection. According to research, Mona Lisa is seen by more than 20,000 people every day. Due to the 
large number of visitors and its fragility, each visitor can see the work for 30 seconds from a certain distance. Therefore, the virtual reality experience created by combining moving image, sound and interactive design has facilitated access to information and democratized access to the artwork.

Augmented Reality (AR) technology is an important digital tool in carrying out the mission of museums to dialogue and inform the public and encourages greater participation. For example, in July 2017, Art Gallery of Toronto (AGO) launches an AR installation called ReBlink with digital artist Alex Mayhew (Coates, 2020). Viewers use a tablet or mobile phone, and in Mayhew's exhibition, they see different versions of the paintings, along with their originals, in which industrial and technological visual images are placed and animated. In AGO's survey with the audience, museum visitors have an average of only 2.31 in front of each painting. It was determined that he spent seconds. Reproducing the time and participation of the audience in the museum, providing information transfer AR and VR technologies.

Museums know how to use digital Technologies and platforms and turn them into advantages in accordance with the requirements of the age. During the pandemic in 2020, many museums attracted the audience with contactless information and visits with QR codes displayed in the venue. When viewers take a picture of the code with their smartphones, they are directed to a specific site that can provide information about exhibitions and artists. Information about current and future exhibitions and events, as well as museum-specific apps, maps and programs can be provided to the viewers. They can also link to visitor surveys that provide museums with valuable information about guest experiences. For example, the Detroit Institute of Arts has launched a mobile tour called Lumin that uses videos, photos, animations and sounds, as well as AR and 3D Mapping, to provide its audience with more information about exhibits through their personal smart devices (Spencer, 2020). The Toledo Art Museum offered visitors a free downloadable application with multimedia guides and audio commentary. Life-changing phone features for the disabled, voice control features, applications that convert speech to text and applications that explain text in a photo to visually impaired users are available in this application. These applications for touch screens encouraged the audience to participate during the pandemic and provided democratic access to artworks for those with visual and hearing impairments.

Kati Price (Price, 2014), head of the digital media department of the Victoria Albert Museum, states that the future museums will put more emphasis on the social functions, and newer generation technologies such as the Internet of Things (IOT) can be used to create personalized experiences.

\section{CONCLUSION}

Today, Museums of contemporary art have features that pursue the public good, collaborate mor with the community and steakholders, focus on participation rather than presentation, and develop online (as well as physical) experiences. It can be said that the use of digital technology has created an acceleration in the diversification of the service areas of museums, in the fulfillment of their increasing social responsibilities including education and training, and in ensuring community participation.

Contemporary art museums make use of all the possibilities of digital technology by establishing public space, spreading information, preserving and transmitting culture through web pages and social networks they use. Analyzes to be made with digital measurements constitute an important part of communication strategies. Viewers are also content producers. For the social values that museums create interactively and for their own values that they will create in this context, national and international accessibility is important in the projects they will realize with correct communication.

"Museums have no borders, they have a network" This discourse on ICOM's Web landing page is an emphasis on the networking of contemporary museums relationships with each other, their stakeholders and society, and is a reference to digital network technology.

Contemporary art museums are part of the scientific, cultural and international relations network. In the understanding of contemporary museology, where communication and social roles come to the fore, contemporary art museums, which add the influence and attraction of art, have turned into a global power factor. The possibilities of digital technology and digital platforms have become a catalyst by accelerating, diversifying and making the relationship of contemporary art museums transparent with society.

In addition, digital communication technologies have turned into an artistic tool and even a method, making the digitalization processes of contemporary art museums obligatory. 


\section{REFERENCES}

[1] Artun, A.: "Art at the Border of Modernity- Criticism, Autonomy, Politics", URL: http://www.aliartun.com/yazilar/modernligin-sinirinda-sanat-sanat-ve-elestiri/ (last request: 202008-10).

[2] Atabek, Ü.: "Communication and Technology", (Seçkin Publishing, Ankara, 2001.), page 37.

[3] Atagök, T.: "The ABC of Museology", (Ege Publications, Istanbul, 2012.), pages 171-176.

[4] Birol, Ö.: "Museology and Marketing in Pera Museum", URL: https://www.youtube.com/watch?v=LOmHRmVdgVs\&t=669s (last request: 2020-08-10).

[5] Castells, M.: "The Rise of Network Society", (Wiley-Blackwell, Hoboken NJ, 2000), page 70.

[6] Coates, C.: "How Museums are using Augmented Reality", URL: https://www.museumnext.com/article/how-museums-are-using-augmented-reality/ (last request: 2020-09-20).

[7] Ertürk, N., Uralman, H.: "The ABC of Museology", (Ege Publications, Istanbul, 2012.), pages 191-193.

[8] Feldman, T.: "An Introduction to Digital Media", (Routledge, New York, 1997.), page 3.

[9] Groys, B.: "Art in the Internet Age in Streaming", (Koç University Publications, Istanbul, 2017.), pages 20-21.

[10] ICOM, “Museum Definition”, URL: https://icom.museum/en/resources/standardsguidelines/museum-definition/, (last request: 2020-08-10).

[11] Köksal, A, H.: “Contemporary Art Talks", (Okan University Publications, Istanbul, 2016.), pages 118-135.

[12] Lorente, J, P.: "Contemporary Art Museums", (Koç University Publications, Istanbul, 2016.), pages 197-210.

[13] Masuda, Y.: "The Information Society Reader", (Routledge, London, 2004.), pages 15-20.

[14] McSweeney, K.: “Open Museum: Approaches to Participation", URL: https://www.youtube.com/watch?v=xolyfoih1xs\&t=294s, (last request: 2020-08-10), 2018.

[15] Price, K.: "How can technology improve the museum experience?", URL: https://www.vam.ac.uk/blog/digital/how-can-technology-improve-the-museum-experience, (last request: 2020-08-10).

[16] Project-musa: "Museum of the Future", URL: http://www.project-musa.eu/wpcontent/uploads/2017/03/MuSA-Museum-of-the-future.pdf, (last request: 2020-08-10).

[17] Schweibenz, W.: "The Development Virtual Museums", URL: http://archives.icom.museum/pdf/E_news2004/p3_2004-3.pdf, (last request: 2020-08-10).

[18] Spencer, K.: "Leveraging Smartphone Technology to Protect Museum Visitors", URL: https://www.aam-us.org/2020/07/03/leveraging-smartphone-technology-to-protect-museumvisitors/ (last request: 2020-08-10).

[19] Tate: "Tate Reports", URL: https://www.tate.org.uk/about-us/tate-reports (last request: 2020-08-10).

[20] Toffler, A.: "Third wave A Classic of Futuristic Economic Analysis", (Koridor Publishing, Istanbul, 2018), pages 436-438.

[21] VIVE Arts: "Mona Lisa: Beyond the Glass", URL: https://arts.vive.com/us/articles/projects/artphotography/mona_lisa_beyond_the_glass/ (last request: 2020-08-10).

[22] Yücel, D.: "Changing Arts And Institutions In The Axis Of Digital Technologies", Genç Sanat, (202), 32-39, 2012b

[23] Yücel, D.: "New Media Art and New Museology: Evaluation of Digital Art Practices in a Museological Context", (Anahtar Books Publishing House, Istanbul, 2012a.), pages 134-152.

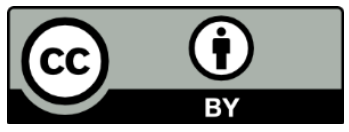

(C) 2020 Authors. Published by the University of Novi Sad, Faculty of Technical Sciences, Department of Graphic Engineering and Design. This article is an open access article distributed under the terms and conditions of the Creative Commons Attribution license 3.0 Serbia (http://creativecommons.org/licenses/by/3.0/rs/). 